\title{
Antiplasmodial activity of aqueous leaf extract of Cymbopogon citratus against Plasmodium falciparum infected rats
}

\author{
Shekins Osheke Okere ${ }^{1}$, Janet Olayemi Sangodele ${ }^{1,2, ~ *}$, Eunice Ogunwole ${ }^{3}$, Moses Dele Adams ${ }^{1}$, \\ Mercy Omoye Shafe ${ }^{3}$ \\ ${ }^{1}$ Department of Biochemistry, Bingham University, Karu, Nigeria \\ ${ }^{2}$ Department of Biochemistry, Federal University of Technology, Akure, Ondo State, Nigeria \\ ${ }^{3}$ Department of Physiology, Bingham University, Karu, Nigeria
}

Email address:

debbie.janet@yahoo.com (J. O. Sangodele)

To cite this article:

Shekins Osheke Okere, Janet Olayemi Sangodele, Eunice Ogunwole, Moses Dele Adams, Mercy Omoye Shafe. Antiplasmodial Activity of Aqueous leaf Extract of Cymbopogon citratus against Plasmodium falciparum Infected Rats. American Journal of Biomedical and Life Sciences. Vol. 2, No. 3, 2014, pp. 60-64. doi: 10.11648/j.ajbls.20140203.12

\begin{abstract}
In Nigeria, malaria is a major public health problem and there are high cost of the effective antimalarial drugs, poor quality drugs and increased emergence of Plasmodial resistance. Thus, there is a need for alternative source of medicine in malaria treatment and prevention. The antimalarial potential of aqueous leaf extracts of Cymbopogon citratus was investigated in this present study. Twenty five Swiss albino rats with average weight of $30.80 \mathrm{~g}$ were distributed into five groups (A, B, C, D and E) with five mice per group. Group B was infected with $0.2 \mathrm{ml} \mathrm{O}^{+}$human parasitized blood of Plasmodium falciparum and $0.1 \mathrm{ml}$ Chloroquine (Bini Laboratories Pvt Ltd). Group C, D, and E were infected with $0.2 \mathrm{ml}$ $\mathrm{O}^{+}$human parasitized blood of Plasmodium falciparum treated with $40 \mathrm{mg} / \mathrm{kg}, 80 \mathrm{mg} / \mathrm{kg}$ and $120 \mathrm{mg} / \mathrm{kg}$ of Cymbopogon citratus extracts respectively for three days. The mice infected with $0.2 \mathrm{ml} \mathrm{O}^{+}$human parasitized blood of Plasmodium falciparum were observed for 72 hours for general symptoms of malaria. The mice tail was punctured, blood was examined under light microscope (x10) resolution) and several malaria parasites were found. Significant decrease of parasitemia levels was observed in $120 \mathrm{mg} / \mathrm{kg}$ body weight treated group compared to $0.1 \mathrm{ml}$ Chloroquine the positive control. The result showed that Cymbopogon citratus possessed a good antimalarial property and can be use for prophylactic and chemotherapeutic purposes.
\end{abstract}

Keywords: Cymbopogon citratus, Chloroquine, Blood, Plasmodium falciparum

\section{Introduction}

In Sub-Saharan Africa, medicinal herbs have been used in the treatment of malaria in endemic regions of the world. Malaria is a major cause of morbidity and mortality in the world and it account for about 216 million cases and about 655000 deaths in 2010 according to WHO. Malaria is caused by different species of Plasmodia including Plasmodium vivax, Plasmodium ovale, Plasmodium malariae and Plasmodium falciparum. Thus, Plasmodium falciparum is the most deadly specie and it gives the highest malaria cases in the world [1,2]. In Nigeria, malaria is a major public health problem and there are high cost of the effective antimalarial drugs, poor quality drugs and increased emergence of Plasmodial resistance. Hence, there is a need for alternative source of medicine in malaria treatment and prevention. Cymbopogon citratus also known as Lemon grass is a perennial grass of about 55 species found mostly in warm region, especially in tropical and subtropical countries [3]. Cymbopogon citratus belongs to the Poaceae family which is monocotyledonous aromatic perennial having slender sharp edged leaves and pointed apex [4]. Cymbopogon citratus consists of citral as the biologically active constituent with more than $75 \%(\mathrm{w} / \mathrm{w})$ of its essential oil [5]. Cymbopogon citratus is widely used in Asia as cuisines because of its sharp lemon flavour. In India it is used as sedatives, febrifuge and immunostimulant [6,7] In Nigeria, it is used for stomach problem and typhoid [8,9]. Since the beginning of human 
history, all natural plants are rich source of medicinal agents and have been in practice as folk medicine, especially in traditional medicine [10]. Medicinal plants have one or more parts of substances that can be useful for the therapeutic purpose [11]. It has been reported that Cymbopogon citratus are being used as the therapeutic agent for the treatment of gastrointestinal disturbances, nervous and hypertension. The essential oils of Cymbopogon citratus were found to produced $86.6 \%$ suppression in growth of Plasmodium berghei when compare to a standard drug chloroquine [12] The extract of Cymbopogon citratus consist majorly citral approximately $65-85 \%$ and small quantity of geranyl acetate, monoterpene olefins and geraniol [13]. The extracts of Cymbopogon citratus are also used in elephantiasis, coughs, flu, headache, gingivitis, leprosy, ophthalmia, vascular disorders and pneumonia. [14,15,16,17,18]. Moreover, studies of Cymbopogon citratus extracts have been reported to have antifungal, antibacterial and antiviral activities antiviral [19]. Gore et al reported the anti helminthes activities of Cymbopogon citratus [20]. World Health Organization estimated 2 billion people with malaria infection (WHO, 2012). The purpose of present study is to investigate the antiplasmodial effect of Cymbopogon citratus on Plasmodium falciparum infected mice.

\section{Material and Methods}

\subsection{Drug}

Chloroquine was manufactured by Bini Laboratories Pvt Nashik India and obtained from Pharmacy section of Bingham University Clinic, Karu, Nasarawa State Nigeria.
Fresh leaves of lemon grass (Cymbopogon citratus) was bought from Masaka market a suburb of Abuja and was identified by Prof Asenge, Department of Biological sciences, Bingham University, Nigeria. The leaves were dried at room temperature and blended into powder, then stored in a plastic container to prevent moisture absorption and contamination. The powdered sample was extracted in $200 \mathrm{ml}$ of $95 \%$ methanol at a temperature of $95^{\circ} \mathrm{C}$ for an hour and 30 minutes using the soxhlet apparatus as described by Harbone (1993). The crude methanolic extracts obtained was concentrated by evaporation on a water bath at $100^{\circ} \mathrm{C}$ for 1 hour then stored in a sample bottle. The percentage yield determined as follows:

Percentage yield $(\%)=\frac{\text { weight of the crude extract }}{\text { Weight of the dried plant sample used }} \times 100$

The extract was reconstitute by dilution (in distilled water) to various concentrations of $250,200,150,100$ and $50 \mathrm{mg} / \mathrm{ml}$ as described by Akujobi et al. (2004) before using for treatment.

\subsection{Experimental Design}

A total number of 25 albino mice of average weight $30.80 \mathrm{~g}$ were used for the experiment. They were distributed into five groups (A, B, C, D and E) with five mice per group. Group B (Experimental control) was administered with $0.2 \mathrm{ml} \mathrm{O}^{+}$human malaria parasite and $0.1 \mathrm{ml}$ Chloroquine (Bini Laboratories Pvt Ltd). Group C, D, and E represents the Treatment groups and was administered with $0.2 \mathrm{ml} \mathrm{O}^{+}$human malaria parasite treated with 40 $\mathrm{mg} / \mathrm{kg}, 80 \mathrm{mg} / \mathrm{kg}$ and $120 \mathrm{mg} / \mathrm{kg}$ of extracts respectively as can be seen in the table below:

\subsection{Plant Material}

Table 1. Experimental Design

\begin{tabular}{lll}
\hline Groups & Descriptions & Treatment \\
\hline A & Normal control & Administered with distilled water, no infection, no treatment. \\
B & $\begin{array}{l}\text { Experimental } \\
\text { control }\end{array}$ & Administered with $0.2 \mathrm{ml} \mathrm{O}^{+}$human malaria parasite and treated with $0.1 \mathrm{ml}$ chloroquine. \\
C & Treatment group 1 & Administered with $0.2 \mathrm{ml} \mathrm{O}^{+}$human malaria parasite and treated with $40 \mathrm{mg} / \mathrm{kg}$ of Cymbopogon citratus extracts. \\
D & Treatment group 2 & Administered with $0.2 \mathrm{ml} \mathrm{O}^{+}$human malaria parasite and treated with $80 \mathrm{mg} / \mathrm{kg}$ of Cymbopogon citratus extracts. \\
E & Treatment group 3 & Administered with $0.2 \mathrm{ml} \mathrm{O}^{+}$human malaria parasite and treated with $120 \mathrm{mg} / \mathrm{kg}$ of Cymbopogon citratus extracts \\
\hline
\end{tabular}

\subsection{Infection of Malaria in Mice}

$0.2 \mathrm{ml}$ of parasitized human blood of blood group $\mathrm{O}$ was obtained from the haematology Department of the Asokoro General Hospital, Abuja. This was injected into a mouse weighing $30.85 \mathrm{~g}$ intra-peritoneally and was observed for about 72 hours for general symptoms of malaria. The tail was punctured and a representative quantity of blood was obtained which was smeared on a glass slide to prepare a thick blood film. On examination under the low power of a light microscope (x10 resolution), several malaria parasites were found, showing that the mouse was positive for malaria parasite. The parasitized mouse was sacrificed and from it, blood was obtained and diluted, using normal saline solution in the proportion 9:1 (9ml of blood: $1 \mathrm{ml}$ of normal saline), with which the remaining experiment mice were infected with malaria parasite.

\subsection{Phytochemical Screening of Plant Extract}

Chemical tests were carried out on the methanolic 
extracts using standard procedures to identify the constituents as described by Sofowara (1993), Trease and Evans (1989) and Harborne (1973).

\subsubsection{Test for Tannis}

About $0.5 \mathrm{ml}$ of the methanolic extracts was put in a test tube and a few drops of $0.1 \%$ ferric chloride was added and observed for brownish green or blue black colouration.

\subsubsection{Test for Flavonoids}

$1 \mathrm{ml}$ of the methanolic extract was heated with $10 \mathrm{ml}$ of ethyl acetate over a steam bath for $3 \mathrm{~min}$. the mixture was filtered and $4 \mathrm{ml}$ of the filtrate was shaken with $1 \mathrm{ml}$ if dilute ammonia solution. A yellow colouration was observed indicating a positive test for flavonoids.

\subsubsection{Test for Terpenoids (Salkowski Test)}

$1 \mathrm{ml}$ of the methanolic extract was mixed in $2 \mathrm{ml}$ of chloroform, and concentrated $\mathrm{H}_{2} \mathrm{SO}_{4}(3 \mathrm{ml})$ was carefully added to form a layer. A reddish brown coloration of the inter face was formed to show positive results for the presence of terpenoids.

\subsubsection{Test for Cardiac Glycosides (Keller-Killani Test)}

$0.5 \mathrm{ml}$ of the methanolic extract was treated with $2 \mathrm{ml}$ of glacial acetic acid containing one drop of ferric chloride solution. This was under layed with $1 \mathrm{ml}$ of concentrated sulphuric acid. A brown ring at the interface indicates a deoxysugar characteristic of cardenolides. A violet ring may appear below the brown ring, while in the acetic acid layer, a greenish ring may form just gradually throughout thin layer.

\subsubsection{Test for Anthraquinones}

$1 \mathrm{ml}$ of the extract was boiled with $5 \mathrm{ml}$ diluted $\mathrm{H}_{2} \mathrm{SO}_{4}$ and filtered while hot. The filtrate was shaken with $5 \mathrm{ml}$ of chloroform. The chloroform layer was pipette into another test tube and $1 \mathrm{ml}$ of diluted ammonia was added. The resulting solution was observed for color change.

\subsubsection{Test for Alkaloids}

$0.5 \mathrm{ml}$ of the methanolic extracts was stirred in $5 \mathrm{ml}$ of $1 \% \mathrm{HCL}_{\mathrm{aq}}$ on a steam bath for 5 mins. The mixture was then filtered using Whatman's no 1 filter. To filtrate, 2-4 drops of Dragendoff's reagent was added to $1 \mathrm{ml}$ of the filtrate. An orange color was observed indicating the presence of alkaloids.

\subsection{Determination of Parasitemia Level in Experimental Animals}

The level of parasitemia in the experimental animals was determined haematologically, using microscopic technique. (Herbert and Lumsdem 1976) The blood samples were obtained from the experimental animals, thick and thin film was prepared on a glass stand. The film was stained (Giemsa stain), and then viewed under low powered microscope (x 10 resolution) to determine the parasitemia level. The level of parasitemia was determined once daily and was closely monitored for 3 days.

\section{Results}

Table 2. Phytochemical Screening of Cymbopogon citrates leaf extract

\begin{tabular}{ll}
\hline Phytochemicals & $\begin{array}{l}\text { Cymbopogon citrates leaf } \\
\text { extract }\end{array}$ \\
\hline Alkaloids & +++ \\
Flavonoids & +++ \\
Tannins & +++ \\
Saponins & +++ \\
Terpenoids & ++ \\
Anthraquinones & ++ \\
Cardiac glycosides & +++ \\
\hline
\end{tabular}

Legend: $+++=$ High,$++=$ Moderate $;+=$ Low $\pm=$ Inconclusive.

Table 3. Number of parasites per field in experimental animals.

\begin{tabular}{clccc}
\hline & & \multicolumn{3}{c}{ Post Infection Days } \\
Group & Treatment & Day 1 & Day 2 & Day 3 \\
\hline A & Normal control & - & - & - \\
B & Experimental control & $81+2.10$ & $16+2.22$ & $10+1.65$ \\
C & Treatment group & $80+2.05$ & $16+1.55$ & $8+1.85$ \\
D & Treatment group & $70+2.32$ & $15+2.10$ & $4+1.42$ \\
E & Treatment group & $67+2.22$ & $12+1.05$ & $0+0.50$ \\
\hline
\end{tabular}

Values are mean for five determination $+\mathrm{SD}$.

Table 4. Amount of daily consumption by mice.

\begin{tabular}{|c|c|c|c|c|}
\hline \multirow[b]{2}{*}{ Group } & \multirow[b]{2}{*}{ Treatment } & \multicolumn{3}{|c|}{ Post Infection Days } \\
\hline & & Day 1 (G) & $\begin{array}{c}\text { Day } 2 \\
\text { (G) }\end{array}$ & Day 3 (G) \\
\hline A & Normal control & 50.00 & 50.00 & 50.00 \\
\hline B & $\begin{array}{l}\text { Experimental } \\
\text { control }\end{array}$ & 4.50 & 5.70 & 30.50 \\
\hline $\mathrm{C}$ & Treatment group & 4.00 & 10.00 & 28.00 \\
\hline $\mathrm{D}$ & Treatment group & 3.00 & 12.00 & 35.50 \\
\hline $\mathrm{E}$ & Treatment group & 2.50 & 8.00 & 41.00 \\
\hline
\end{tabular}

\section{Discussion}

Cymbopogon citratus are very well known to provide a rich and diverse source therapeutic agent for the treatment of gastrointestinal disturbances, nervous and hypertension. [21]. A number of previously conducted report indicated that that Cymbopogon citratus has been used against gastrointestinal disturbances and complications [22]. It has been reported that Chromatographic fraction of Cymbopogon citratus essential oil in agar plate was active on Bacillus subtilis, Escherichia coli, Staphylococus aureus [23,24] and Salmonella paratyphi, Shigella flexneri. [25,26] In this study the aqueous extract of Cymbopogon citratus showed antiplasmodial activity. Administration of $0.1 \mathrm{ml}$ of chloroquine, $40 \mathrm{mg} / \mathrm{kg}, 80 \mathrm{mg} / \mathrm{kg}$ and $120 \mathrm{mg} / \mathrm{kg}$ body weight of aqueous extracts of Cymbopogon citratus reduced the level of parasitemia significantly after three days of treatment in the different treatment groups. The group treated with $120 \mathrm{mg} / \mathrm{kg}$ body weight of extracts of Cymbopogon citratus produced the most significant 
reduction in the level of parasitemia. It was observed that the level of parasitemia was highest on the first day of treatment while the amount of food consumed was lowest. The animals showed sign of weakness and sluggishness prior to commencement of treatment. Level of feed consumption was also observed to be low in the experimental animals when compared to the normal control group. Appetite level was found to be the highest on the last day of treatment, probably due to the facts that parasitemia has almost be completely eradicated (Table 4). The experimental groups treated with $40 \mathrm{mg} / \mathrm{kg}$ and $80 \mathrm{mg} / \mathrm{kg}$ recorded minimal troughs of parasitemia on day 3 the group treated with $120 \mathrm{mg} / \mathrm{kg}$ body weight extract recorded a total eradication of the third day of treatment.

\section{Conclusion}

From the results of this preliminary work, it is concluded that aqueous extract of Cymbopogon citratus showed antiplasmodial activity and could be apply as an effective agent in future after further exploration. Studies should be needed in next steps of the undertaken work for understanding the mechanism of action by using in vitro models to figure out the effectiveness and pharmacological rationale of using Cymbopogon citratus as an antimalaria drug with chloroqiune as positive control.

\section{Ethical Approval}

All authors hereby declare that "Principles of laboratory animal care" (NIH Publication No. 85-23, revised 1985) were followed, as well as specific national laws where applicable. All experiments have been examined and approved by the appropriate ethics committee of the Bingham University, Karu, Nigeria. All authors hereby declare that all experiments have been examined and approved by appropriate ethics committee and have therefore been performed in accordance with the ethical standards laid down in the 1964 Declaration of Helsinki.

\section{Conflict of Interest}

There are no conflicts of interests on this research work.

\section{Acknowledgements}

We appreciate the contribution of the Department of Biochemistry, Bingham University, Karu, Nigeria for all the assistance towards the success of the study.

\section{References}

[1] WHO. Training module on malaria control: Malaria Case Management Guide for Participants. World Health Organization (WHO); $2013 . \quad$ Available: http://apps.who.int/iris/bitstream/10665/78070/1/978924150 3976_eng.pdf
[2] KFF. The Global Malaria Epidemic- Fact Sheet: US Global Health Policy. (2013) The Henry J. Kaiser Family Foundation; Available: http://kaiserfamilyfoundation.files.wordpress.com/2012/10/ 7882-04-2.pdf.

[3] Cheel J, Theoduloz C, Rodríguez J, Schmeda-Hirschmann G (2005). Free radical scavengers and antioxidants from Lemongrass (Cymbopogon citratus (DC.) Stapf.) J. Agric. Food Chem. 53: 2511-2517.

[4] Ernst, E. (2008). "Chiropractic: a critical evaluation". Journal on Pain Symptom Management 35 (5): 544-6213.

[5] Huynh KP, Maridable J, Gaspillo P, Hasika M, Malaluan R, Kawasaki J (2008). Essential oil from lemon grass extracted by supercritical carbon dioxide and steam distillation. The Phillippine Agric. Sci. 91: 36-41.

[6] Pearson O (2010). The Antibacterial Properties of Essential Oils. http://www.livestrong.com/article/168697-theantibacterialproperties-of-essential-oils

[7] Brian TS, Ikhlas AK (2002). Comparison of extraction methods for marker compounds in the essential oil of lemongrass by GC. J. Agric. Food Chem. 50: 1345-1349.

[8] Aibinu I, Adenipekun T, Adelowotan T, Ogunsanya T, Odugbemi $T$ (2007). Evaluation of the antimicrobial properties of different parts of Citrus aurantifolia (lime fruit) as used locally. Afr. J. Tradit. CAM. 2: 185-190.

[9] Depken KL (2011). Properties of Lemon Grass. http://www.ehow.com/about_5382246_propertieslemongrass. html.

[10] Bonjar, G.H.S \& Farrokhi, P.,R. (2004). Antibacillus activity of some plant used intraditional medicine of Iran. Nigerian Journal on National Prod. Med. (8): 34-39.4.

[11] Rios, J.L \& Recio, M., C. (2005). Medicinal plants and antimicrobial activity. Journal of Ethnopharmacology 100: 80-84.

[12] Tchoumbougnang, F; Zollo, P.H.A; Dagne, E; Mekonnen, Y. Planta Med., (2005), 71, 20-23.

[13] Fair, J.D \& Kormas, C.M. (2008). Journal on Chromatography, 1211 (1-2), 49-54.

[14] Onawunmi G.O. (1989) Evaluation of the antimicrobial activity of citral. Lett Appl Microbiol 9:105-8.24.

[15] Wannissorn B., Jarikasem S., Soontorntanasart T. (1996) Antifungal activity of lemon grass and lemon grass oil cream. Phytotherapy Res 10:551-4.40.

[16] Schuck V.J.A., Fratini M., Rauber C.S., (2001) Avaliação da atividade antimicrobiana de Cymbopogon citratus Revista Brasileira de Ciências Farmacêuticas 37:45-9

[17] Paranagama P.A., Abeysekera K.H.T., Abeywickrama K., Nugaliyadde L. (2003) Fungicidal and anti-aflatoxigenic effects of the essential oil of Cymbopogon citratus (DC.) Stapf (lemon grass) against Aspergillus flavus Link. Isolated from stores rice. Lett Appl Microbiol 37:86-90

[18] Wannissorn B., Jarikasem S., Siriwangechain,T., Thubthimthed, S. (2005) Antibacterial properties of essential oils from Thain medicinal plants. Fitoterapia 76:233-6. 
[19] Minami M., Kita M., Nakaya T., (2003) The inhibitory effect of essential oils on Herpes simples virus type-1 replication in vitro Microbiol Immunol; 47: 681-4.

[20] Coles GC. (1997) Nematode control practices and anthelminthic resistance on British sheep farms. Vet. Rec; 141: 91-93.8.

[21] Deore S. L., S. S. Khadabadi, Kamdi K. S., Ingle V. P., Kawalkar N. G. Sawarkar P. S, Patil U. A, Vyas A. (2009) In vitro Anthelmintic activity of Cassia tora. International Journal of Chem Tech Research. Vol.1, No.2, pp 177-179,

[22] Nakamura, Y.; Miyamoto. M.; Murakami, A.; Ohigashi, H.; Osawa, T \& Uchida. K. (2003). A phase 11 detoxification enzyme inducer from lemon grass: identification of citral. 23.
[23] Onawunmia, G.O; Yisak, W. A. and Ogunlana, E.O., Journal of Ethnopharmacology, (1984), 12, 279-286.

[24] Bate Smith E.C. (1962) The phenolic constituent of plants and their taxonomic significance, dicotyledons. J Linn Soc Bot 58:95 - 103.3.

[25] Melo, S.F; Soares, S.F; da Costa, R.F; da Silva, C.R; de Oliveira, M.B; Bezerra R.J; Caldeira-de-Araujo A; and Bernardo-Filho M., (2001) Mutat Res, 496, 33-38.

[26] Syed, M; Khalid, M.R. and Chaudhary, F.M., (1990) Pak J Sci Ind Res., 33, 529-531. 